\title{
Educators' responses to policies and accountability expectations
}

\author{
Stephan Gerhard Huber ${ }^{1} \cdot$ Guri Skedsmo $^{1,2}$
}

Published online: 17 November 2016

(C) Springer Science+Business Media New York 2016

Policy instruments are often utilised regarding the set of techniques or means used by governmental authorities to achieve the ends the authorities are pursuing (Vedung 1998). From a functionalist perspective, they are often looked upon as technical approaches to solving political problems, and research is primarily occupied with issues such as the relevance and effectiveness of instruments with respect to policy implementation, aiming to devise improved solutions (Lascoumes and Le Gales 2007). An alternative way is to define policy instruments as

[...] a device that is both technical and social, that organizes specific social relations between the state and those it is addressed to, according to the representations and meanings it carries (Lascoumes and Le Gales 2007, p. 4).

This definition considers a theorised relationship between the governing and the governed, and emphasis is placed on the role of various key actors in school-governing processes. How they interpret and respond to policy initiatives, instruments and the introduced accountability approaches will depend on their subjective theories. Accountability generally implies managing various expectations generated by various actors in society, and accountability seems to be constituted through roles and relationships by following rules. In addition, it is influenced by context (cf. Romzek and Dubnick 1987). In defining accountability relationships, the concept of role and authority, either as a part of the role in a hierarchy or in terms of expertise or societal influence, seems to be crucial.

Stephan Gerhard Huber

stephan.huber@phzg.ch

$\triangle$ Guri Skedsmo

guri.skedsmo@ils.uio.no

1 Institute for the Management and Economics of Education, University of Teacher Education Zug, Zug, Switzerland

2 Department of Teacher Education and School Research, University of Oslo, Oslo, Norway 


\section{Articles in this issue of EAEA 4/2016}

The four articles in this issue address different aspects and topics related to educators' role in policy implementation as well as managing and mediating diverse accountability expectations.

In the first paper, Ehren and Shackleton raise questions with respect to whether proportional risk-based inspection models are the way forward to improve schools in the Netherlands. This type of inspection targets high-risk schools for visits, while schools with satisfactory student attainment levels are excluded from inspections. The researchers base their analysis of the impact school inspections have on schools' outcomes over a time period during which they compare schools placed in different inspection treatment categories (weak/very weak and basic) after the early warning analysis. In doing so, Ehren and Shackleton find differences in improvement trajectories. Interestingly, the timeline of the improvements in the weak/very weak schools seems to coincide with the inspection consequences, where sanctions kick in 2 to 3 years after the schools are categorised. The authors problematise unintended consequences of the high pressure put on these schools, to which schools may respond with short-term fixes to show speedy results. A devaluing of the school in terms of fewer students applying to it and a decrease in satisfaction among the current student population create additional pressure.

How principals manage to juggle pressure in their attempt to respond to multiple accountability demands is the topic of the second paper. Based on case studies of three school sites located in Ontario, Canada, where performance-based accountability seems to be a dominating approach, Pollock and Winton find that other types of approaches may differ according to the local school context. In addition to working towards improving student achievements as measured by standardised tests, each principal had to align this focus with other types of expectations, such as addressing social justice efforts to minimise the influence of poverty on student learning, keeping a focus on values and beliefs that correspond with the Catholic faith or implementing strategies and balancing community needs with an emphasis on following up goals stated in the school improvement plan. The authors argue that the success of the principals depends on their ability to negotiate different demands and juggle tensions that may emerge in certain situations, especially between addressing national performative demands to raise test scores and prioritising local matters.

Teodorović et al. analyse characteristics and patterns of three educational reforms in Serbia through the lens of key actors: principals, teachers and counsellors who all have key roles in their implementation. Immediately after the major political changes in 2000 , Serbian educational authorities began to design and implement policy initiatives intending to contribute to economic revival, democratic development and alignment with policies of other European countries. The authors point to several barriers in the implementation processes such as a general devaluation of the work of principals, teachers and counsellors, political instability and frequent changes of policy direction, which can lead to reform fatigue, a lack of support and resources and delegated authority. While preparing to introduce reforms, they argue authorities failed to create a common ground, which has led to a mismatch of expectations at different levels of the education system. Despite reform shortcomings, however, there seems to be a general positive attitude that the initiatives represent potential improvements. Based on their findings, Teodorović et al. provide recommendations to policy makers regarding how to improve various phases of reform work. 
Since educators' beliefs play an important role in how they go about implementing reforms, Liou, Moolenaar and Daly have designed and piloted an instrument to evaluate principals' and teachers' beliefs regarding the Common Core State Standards (CCSS) in California. So far, 43 states in the USA and the District of Columbia (DC) have adopted the CCSS in mathematics and English language arts. According to the authors, these standards signal a fundamental policy change in education since they aim to provide a consistent and clear understanding of the skills and knowledge that students at the elementary and secondary school levels need to acquire to be college and career ready. Moreover, they call for a deep conceptual understanding of rigorous content as well as the capabilities to apply cross-disciplinary knowledge using high-order skills. Liou et al. have validated an instrument consisting of three sub-constructs on CCSS beliefs about (1) their own efficacy in the implementation process, (2) resources and training and (3) the impact of CCSS on teaching and learning, which can be used to understand the preparedness of educators and support the implementation process.

\section{To interpret, mediate and respond to policies and expectations}

In various ways, the four articles deal with the social effects of the meaning of policy, to which educators are being called upon to respond (Ball 1994, 2008). Ehren and Shackleton point to various unintended consequences of risk-based models of school inspection. It seems as if principals in weak schools feel pressure following inspection categorisation, treatment and sanctions. Their actions to improve measured aspects quickly can be seen as a response to the way this instrument is designed and implemented in practice. Without accompanying accountability approaches and sanctions, they may choose alternative ways that, in similar contexts, have shown sustainable results.

The principals in Pollock and Winton's study seem to concentrate on responding to performance expectations in terms of students' outcomes on standardised tests. At the same time, their success depends on their ability to negotiate and handle other types of expectations generated within the local school context. Teodorović et al. and Liou et al. take a different perspective, as they address the importance of educators' perceptions and values in policy implementation. While Teodorović et al. focus on consequences if reforms are introduced too fast without creating a common ground, Liou et al. concentrate on how to prepare educators for reform policies.

We argue that educators' perspectives on policy, its implementation and accountability practices are crucial. This is why we claim that attention needs to be paid to the design of policy and participatory processes in order to establish a comprehensive understanding and positive assessment by stakeholders. Important factors in the process of assessment include the perceptions of current challenges, the quality of the policy ('doing the right thing'), the design of policy implementation ('doing the right thing rightly'), the anticipation of possible policy impact (for the profession in general and for their own practices in particular), the investment-benefit relation, participation in policy development and the locus of control in policy implementation, competences and resources for implementation and improving practices, prior experiences and attitudes (cf. Huber 2015) - not the least accompanying accountability practices in terms of how their work is followed up (cf. Skedsmo 2009). The thesis is that a comprehensive understanding influences acceptance, which influences motivation, which again influences implementation activities. 
Furthermore, of course, motivation is also influenced by competences needed for implementation (in terms of knowledge, abilities and skills) and attitudes, as well as site-based management (with planning, coordination of actions, support, provided resources etc.). If such subjective theories are not considered, the processes of educators' sense making of the policy can be negatively influenced, and there is the danger that the motivation for policy implementation will decrease. Professional judgement is needed with respect to interpreting and mediating new policies and accountability expectations. We argue furthermore that policy and accountability need to be based on professional knowledge and expertise (from practice and research).

\section{References}

Ball, S. J. (1994). Education reform. A critical and post-structural approach. Buckingham: Open University Press.

Ball, S. J. (2008). The education debate. Bristol: Policy.

Huber, S. G. (2015). Gelingensbedingungen von Evaluation: Bewertung - Akzeptanz - Handeln. In S. G. Huber \& G. Skedsmo (Eds.), Evaluation - Bereicherung oder Belastung? Schulverwaltung Spezial 17 (1) (pp. 8-9). Neuwied: Wolters Kluwer Deutschland GmbH.

Lascoumes, P., \& Le Gales, P. (2007). Introduction: understanding public policy through its instrumentsfrom the nature of instruments to the sociology of public policy instrumentation. Governance: $A n$ International Journal of Policy, Administration, and Institutions, 20(1), 1-21.

Romzek, B. S., \& Dubnick, M. J. (1987). Accountability in the public sector: lessons from the challenger tragedy. Public Administration Review, 47(3), 227-238.

Skedsmo, G. (2009). School governing in transition? Perspectives, purposes and perceptions of evaluation policy. (PhD), University of Oslo.

Vedung, E. (1998). Policy instruments: typologies and theories. In M.-L. Bemelmans-Videc, R. C. Rist, \& E. Vedung (Eds.), Carrots, sticks and sermons. Policy instruments and their evaluation. London: Transaction. 